\title{
Klumme: Realpolitik og dynamik på vej igen i Europa
}

\section{Af Hugo Gaarden}

Efter det franske valg og Kinas afdæmpning af Donald Trump omkring Nordkorea, er der flere tendenser, der viser, at realismen er ved at komme på banen igen efter populismens hærgen

Det går langsomt, men realpolitikken er ved at komme til ære og værdighed igen, og der er lagt op til mere dynamik og selvbevidsthed i Europa. Mens USA står over for en Nixon-lignende krise, er populismen i Europa blevet bremset, og de europæiske lande er ved at komme $i$ arbejdstøjet. På globalt plan er den såkaldte krise om Nordkoreas atomvåben blevet afdæmpet, og der er ved at komme stabilitet omkring Syrien. Sejren for Emmanuel Macron ved det franske præsidentvalg satte et punktum for populismens vækst i Europa, for fremmedfjendskheden og for EU-modstanden. Første skridt kom ved det hollandske valg for nogen tid siden, hvor klar tale fra den siddende regeringschef, Mark Rutte, over for den fremmedfjendske holdning i Holland gav pote.

Der har den seneste tid ikke været vækst i de alternative partier på yderfløjene $\mathrm{i}$ Europa, og i Tyskland er der ved at blive stabilitet omkring de to store midterpartier, hvor kansler Angela Merkels konservative CDU nu har en chance for at bevare regeringsmagten. I den forbindelse er det paradoksalt, at de store, traditionelle midterpartier i Frankrig er blæst af banen, og at franskmændene valgte en person, der stort set var ukendt for to år siden, og som ikke repræsenterer et parti, men snarere en løs bevægelse. Men det udtrykker øjensynlig en bred utilfredshed hos vælgerne mod partier og regeringer, der ikke løser de problemer, som ligger åbent for fødderne af dem, men som de ansvarlige ikke har turdet tage fat på. Populismen har øjensynlig ikke været en bestræbelse på at gå $\mathrm{i}$ en helt anden politisk retning. Modstanden mod fremmede og nationalismen er måske snarere udtryk for en længsel efter stabilitet. Vælgerne vil have kontrol over deres tilværelse, og de vil have løst de eksisterende problemer.

Valget i Frankrig var ikke udtryk for en bevægelse mod højre eller venstre. Det er i Frankrig, at disse politiske begreber blev opfundet, men de har mistet deres betydning $\mathrm{i}$ en tid, hvor det bliver sværere og sværere at se forskel på en 'rød og en blä' politik, og hvor borgernes hverdag bliver mere påvirket af den teknologiske udvikling end af politiske beslutninger.

Macron har skabt tiltro til, at problemerne kan løses. Derfor kan valgsejren føre til, at de europæiske politiske ledere begynder at trække i arbejdstøjet og fx investerer i en bedre infrastruktur og skaber 
arbejdspladser for de unge. Den tidligere italienske regeringschef, Matteo Renzi, har været stærkt angrebet af EU-modstandere, men nu dukker han op igen og vil på en Macron-facon forsøge at holde Italien fast som EU-medlem.

Angela Merkel har virket træt i flere måneder, men hendes parti har vundet de seneste to delstatsvalg, og den nye socialdemokratiske leder, Martin Schulz, har ikke længere fremgang. Han kræver dog massive investeringer, hvis han bliver kansler, og derfor kan den tysk-påtvungne sparekurs i EU blive afløst af flere investeringer, som også Macron går ind for, uanset om Merkel eller Schulz vinder valget i efteråret.

Merkel er desuden blevet aktiv på den internationale scene. Hun forsøger at gøre G20-topmødet i Hamburg i juli mere operativt end tidligere topmøder. Hun kan overskygge Trump som global leder. Det er det første topmøde siden valget af Trump, og det vil omfatte både demokratiske og autokratiske ledere. Merkel forsøger at få verden, som den er, til at fungere bedre. Det er gammeldags realpolitik. Desuden har hun som mål at finde milliarder til investeringer i Afrika for at skabe en udvikling dér og for at bremse den afrikanske indvandring til Europa. Da hun mødtes med præsident Vladimir Putin i Socchi for nylig holdt hun fast i sanktionerne. De kan ikke ophæves, før der kommer en løsning på den russisk støttede konflikt i Østukraine. Men der var ikke noget krav om, at russerne skal tilbagelevere Krim. Tyskerne lukker øjnene for Krim-annektionen. Merkel har også forsøgt at få Saudi-Arabien til at medvirke til en Syrien-løsning. Det er værd at bemærke, at den nye våbenhvile med etablering af fire de-eskalationszoner i Syrien er forhandlet på plads uden Vestens deltagelse (om end NATO-medlemmet Tyrkiet er med i aftalen sammen med Rus- land og Iran). Der er kommet andre aktører end de vestlige på banen.

Det ses især omkring Nordkorea. Kinas præsident, $\mathrm{Xi}$ Jinping, fik den amerikanske præsident, Donald Trump, til at falde til ro omkring Nordkorea. Kina vil ikke have et militært angreb eller bare truslen om det i sit nabolag. Desuden betyder valget af Moon Jae-in som ny præsident i Sydkorea, at Sydkorea vil have en dialog og økonomisk samarbejde med Nordkorea. USA får svært ved at bevare sit missilskjold i Sydkorea, fordi Moon Jae-in vil have bedre relationer til Kina. Kina har sat sig i spidsen for en ny handelsaftale i Stillehavsområdet, efter at Trump har trukket sig ud af TTP-aftalen. Kinas nye version af Silkeruten gennem Asien begynder også at skabe opmærksomhed selv i Europa, fordi det kan skabe en ny dynamik i det euro-asiatiske område. Om ti år er det måske dét og ikke krige og terrorhandlinger i Mellemøsten, der vil præge den globale dagsorden.

I Europa kan vi se frem til mere dynamik med franske reformer, et ny-konstrueret EU efter briternes exit og med en større tysk selvbevidsthed i udenrigs- og sikkerhedspolitikken. Den tyske udenrigsminister, Sigmar Gabiel, har skabt fortørnelse i flere NATO-lande ved at sige, at der ikke nødvendigvis er brug for flere rustningsudgifter i de lande, der ikke lever op til NATOs to pct. målsætning for forsvarsudgifterne. Han mener desuden, at Tyskland og Europa bør definere deres interesser uafhængigt af USA. "Nu kommer det an på os selv," har han udtalt til den tyske ugeavis Die Zeit. Det er nye, selvbevidste toner, men de ligger i forlængelse af tendenser i Tyskland siden valget af Trump, og de vil utvivlsomt tage til, hvis Trumps fyring af FBI-chefen James Comey, ender i en ny Nixon-affære. 


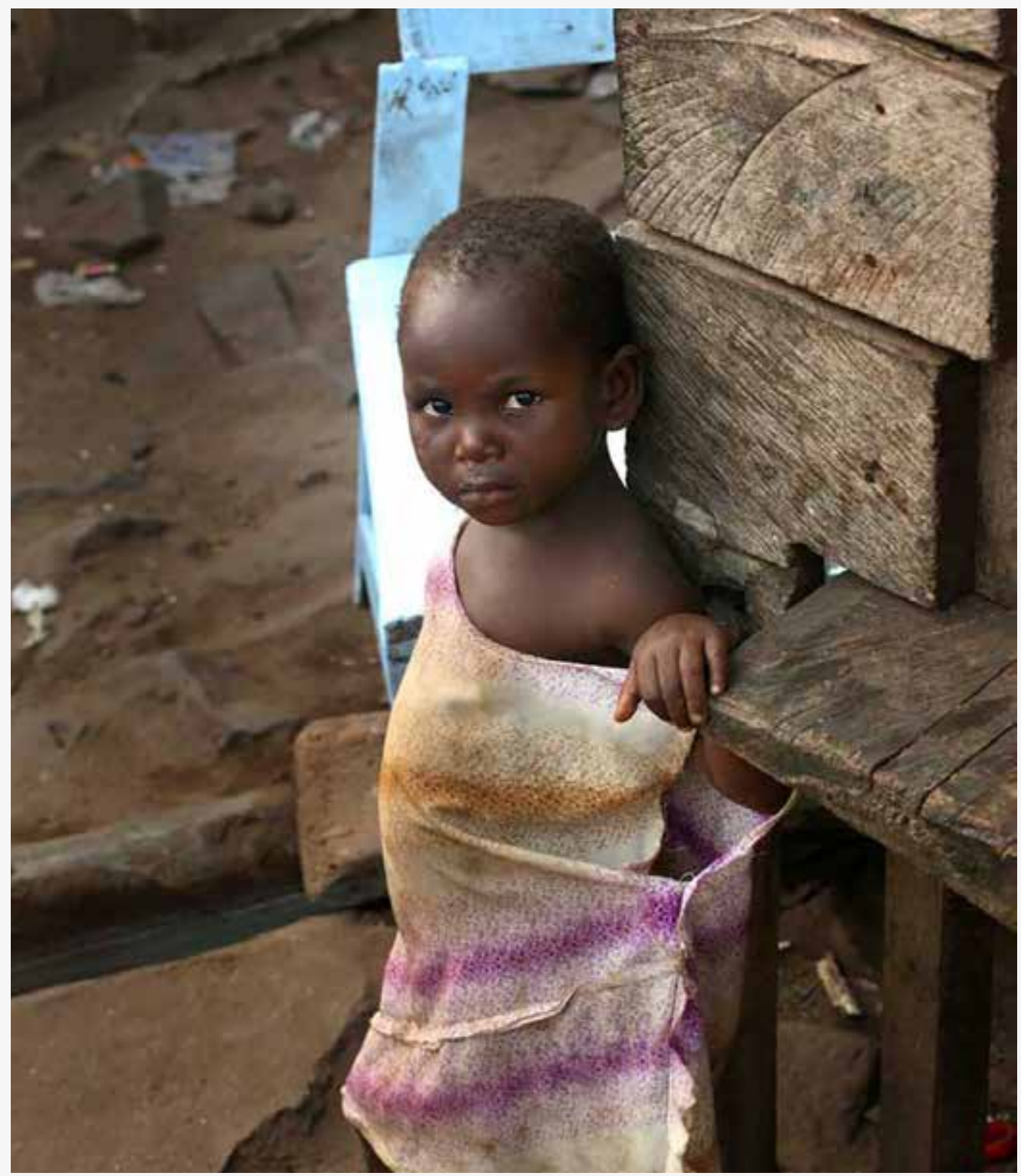

FOTO: Steve Evans fra Citizen of the World via Wikimedia Commons

Billedet er taget i Elmina, Ghana. Selv om Ghana de seneste ti år i gennemsnit har haft en konstant årlig vækst på over syv pct., vokser uligheden, og der er stadig udbredt fattigdom i mange områder. 